\title{
René Girault: em memória
}

\section{JOSÉ FLÁVIO SOMBRA SARAIVA}

Há cinco anos atrás visitava o Brasil, pela primeira e única vez, o estudioso francês das relações internacionais René Girault. Cumpriu programa acadêmico em Brasília, onde participou, como convidado especial, do International Conference on State and Nation in the History of International Relations of American Countries, entre 31 de agosto e 2 de setembro de 1994. O emérito historiador das relações internacionais, então diretor do Institut Pierre Renouvin e presidente da Comissão de História das Relações Internacionais (Comitê Internacional de Ciências Históricas), ficou impressionado com o desenvolvimento dos estudos dessa área no Brasil e com a capacidade de articulação dos estudiosos brasileiros com seus pares argentinos.

A todos que participaram daquele evento, auspiciado pelo Programa de Pós-Graduação em história das relações internacionais da Universidade de Brasília, cativou a simplicidade e os gestos nobres do amadurecido intelectual. Assistiu a todas as sessões de trabalho, fez anotações e interveio no debate. Curioso em relação às interpretações do grupo de historiadores da região platina do continente, Girault não escondeu sua surpresa em perceber o profissionalismo da produção científica local e as adaptações críticas a que a escola historiográfica francesa das relações internacionais foi submetida pelos historiadores do Cone Sul das Américas. Ao deixar Brasília, afirmou que retornava à França modificado em algumas das suas concepções anteriores acerca do papel internacional da América do Sul nos séculos XIX e XX. Deixou claro que havia aprendido muito com os historiadores locais.

Girault despediu-se de todos os seus colegas neste ano de 1999. Acometido de câncer há poucos anos, não resistiu a mais um verão europeu. Deixou-nos a personalidade gentil e cavalheiresca, mas permanece a obra de um dos mais importantes formadores do pensamento histórico mundial sobre a evolução das relações internacionais nos últimos séculos.

Três grandes contribuições intelectuais devem ser atribuídas a Girault. Em primeiro lugar, soube dar continuidade ao trabalho institucional iniciado por Pierre Renouvin e seguido por Jean-Baptiste Duroselle de afirmação dos estudos da história das relações internacionais na França. Herdeiro de uma tradição que rompeu com o ângulo da chancelaria e com as prisões da história diplomática, Girault se inseriu na tradição daqueles que reivindicaram a dimensão societária das relações internacionais. Nesse sentido, laborou na construção de meios para que a escola francesa das relações internacionais pudesse ser respeitada no seio da comunidade acadêmica francesa. 
Educador de várias gerações de estudantes franceses e estrangeiros na Universidade de Paris I (Panthéon-Sorbonne), Girault dirigiu, com grande competência acadêmica, o Instituto Pierre Renouvin. A renomada escola de formação de historiadores das relações internacionais tem, desde 1995, como seu novo diretor, Robert Frank, ex-aluno e colega responsável por levar adiante a tradição na qual Girault tanto militou.

Em segundo lugar, Girault foi autor de uma obra acadêmica consistente no âmbito da história das relações internacionais. Entre outros livros publicados, sua Histoire des relations internationales ${ }^{1}$ é um marco da reflexão da formação do mundo contemporâneo. Defendia, nos últimos anos, uma dimensão civilizacional para a interpretação das diferentes maneiras em que Estados e sociedades atuam na cena internacional. Dotado de uma capacidade analítica invejável, Girault não foi seduzido pelo discurso retórico e prolixo. Ao contrário, sua obra é dotada de um sentido de síntese, de busca dos elementos necessários à explicação e ao convencimento pelo argumento elegante e sustentado nas fontes mais diversas.

Finalmente, Girault deu substancial contribuição à difusão do campo da história das relações internacionais no seio da comunidade mundial de historiadores. Participou de inúmeras conferências internacionais, particularmente européias, que trataram das relações internacionais. Em todas elas, procurava incluir o vigor da interpretação histórica.

Nenhum lugar, no entanto, estará tão saudoso da obra institucional e intelectual de Girault. Refiro-me ao seu trabalho junto à Comissão de História das Relações Internacionais, parte do Comitê Internacional de Ciências Históricas. Esta Comissão congrega cerca de quatro centenas de scholars e se reúnem a cada cinco anos por ocasião do Congresso Internacional de Ciências Históricas, ocasião em que estabelece pautas de pesquisa e programa colóquios anuais em diversas partes do mundo para os cinco anos seguintes. Tendo atuado como presidente da referida Comissão, Girault lutou sempre pela ampliação da participação dos historiadores das relações internacionais de várias regiões do mundo nos trabalhos da mesma. Responsável pela "deseuropeização" da Comissão e por sua ampliação democrática para novos membros, especialmente da América Latina, Girault deixou sua marca de espírito despojado e de profunda sensibilidade profissional.

$\mathrm{O}$ vazio criado pelo desaparecimento do grande intelectual nos anima a seguir o curso do estudo e da difusão da história das relações internacionais. Esse singelo tributo é uma pequena homenagem de brasileiros ao homem e à obra que tanto nos marcaram e que seguirão balizando nossas atitudes morais e intelectuais. 
Nota

${ }^{1}$ GIRAULT, René. Histoire des relations internationales - t. I: Diplomatie européenne; nations et impérialismes, 1871-1914; t. II (em colaboração com FRANK, Robert): Turbulente Europe et nouveaux mondes, 1914-1941; t. III (em colaboração com THOBIE, Jacques \& FRANK, Robert): La loi des géants, 1941-1964 - Paris: Masson, 1985, 1988, 1993. 